\title{
Presidential Particularism and US Trade Politics*
}

\author{
KENNETH S. LOWANDE, JEFFERY A. JENKINS AND ANDREW J. CLARKE
}

$R$ esearch on presidential distributive politics focuses almost exclusively on federal domestic spending. Yet, presidential influence on public policy extends well-beyond grant allocation. Since the early 20th Century, for example, the president has had substantial discretion to adjust tariff schedules and non-tariff barriers "with the stroke of a pen." These trade adjustments via presidential directive allow us to test the logic of presidential particularism in an area of policy understudied among presidency scholars. We examine unilateral adjustments to US trade policies between 1917 and 2006, with a detailed analysis of those made between 1986 and 2006, and find that presidents-in accordance with electoral incentives-strategically allocate trade protections to industries in politically valuable states. In general, states in which the president lacks a comfortable electoral majority are systematically more likely to receive protectionist unilateral orders. Overall, our results show that the president's distributive imperative extends into the realm of foreign affairs, an arena in which the president has substantial authority to influence public policy.

$\mathrm{M}$ ounting evidence suggests that the American presidency may fall well short of a normatively appealing, nationally representative Executive-loyal only to the public interest. In particular, a burgeoning research agenda has highlighted the distributive politics of presidential power (Berry, Burden and Howell 2010; Hudak 2014; Kriner and Reeves 2015a; Kriner and Reeves 2015b). Contrary to past studies, which focus almost exclusively on legislators' efforts to secure funding for their districts, this research has shown that federal resources tend to be allocated in a way that redounds to the benefit of the president and presidential co-partisans.

We further this line of inquiry in two ways. First, scholarship on presidential distributive politics has focused almost exclusively on federal domestic spending. ${ }^{1}$ Yet, presidential influence on public policy extends well-beyond grant allocation. It is plausible, then, that the particularistic imperative would affect other areas of presidency-driven politics. We analyze one of those areas: trade politics. Since the early 20th century, the president has had substantial discretion to adjust tariff schedules and non-tariff barriers (NTBs) "with the stroke of a pen" (Mayer 2001). ${ }^{2}$ In the Reciprocal Trade Agreements Act (RTAA) of 1934 and the Trade Reform Act of 1974, the president was granted wide discretion to adjust trade barriers through presidential directives. These trade adjustments via presidential directive allow us to test the logic of presidential particularism in an area of policy understudied among presidency scholars.

\footnotetext{
* Kenneth S. Lowande, Postdoctoral Research Associate, Department of Political Science, Washington University in St. Louis, Seigle Hall 273, Campus Box 1063, St. Louis, MO 63130-4899 (lowande@wustl.edu). Jeffery A. Jenkins, Provost Professor of Public Policy and Political Science, Director of the Bedrosian Center, Judith and John Bedrosian Chair in Governance and the Public Enterprise, USC Sol Price School of Public Policy, University of Southern California, Lewis Hall 312, Los Angeles, California 90089-0626 (jajenkins@usc. edu). Andrew J. Clarke, Assistant Professor of Government and Law, Lafayette College, 102 Kirby Hall of Civil Rights, Easton, PA 18042 (clarkeaj@lafayette.edu). The authors thank George Krause and Doug Kriner for helpful comments and suggestions. All authors contributed equally to this article. To view supplementary material for this article, please visit http://dx.doi.org/10.1017/psrm.2017.12

1 Kriner and Reeves (2015b, Chapters 2 and 3) are a notable exception.

2 NTBs refer to restrictions on trade — such as licensing requirements and quotas-for which the regulator does not collect a duty.
} 
Second, trade represents an "intermestic" political issue, in that it has direct implications for the foreign affairs of the United States and the prospects of American producers. Given this, the systematic evidence we present is a rare and important example of the president's domestic, particularistic incentives directly affecting the foreign affairs of the United States.

We study unilateral adjustments to trade policies between 1917 and 2006, with a detailed analysis of those made between 1986 and 2006 (which allows us to compare our findings with prior work on presidential distributive politics that has been confined to a similar period). Specifically, we link protectionist adjustments to the interests they directly benefited, and the corresponding political units wherein those interests operated. By connecting protectionist measures for a given commodity and top state producers, we identify which states benefited most from changes in trade policy. We find that presidents, in accordance with electoral incentives, strategically adjust trade barriers. In presidential election years, presidents provide consistent protection to states that are hotly and weakly contested-relative to states that are firmly controlled. And, contrary to prior research, we find presidents are not significantly more likely to allocate protectionist measures to politically vulnerable co-partisans in the House or Senate. These findings suggest that the president's distributive imperative extends beyond domestic spending - into an area of substantial executive discretion.

\section{PRESIDENTIAL PARTICULARISM}

Recent, provocative analyses of federal grants have demonstrated that the distribution of domestic spending reflects the partisan and electoral interests of a particularistic president (Berry, Burden and Howell 2010; Hudak 2014; Kriner and Reeves 2015a; Kriner and Reeves 2015b). Faced with strong incentives as party leaders (Galvin 2010; Milkis, Rhodes and Charnock 2012), presidents use their influence at multiple stages of the budgetary process to aid co-partisans, sway key states in the electoral college, and reward core supporters. The absolute impact of this behavior on federal outlays is striking: Kriner and Reeves, for example, show that between 1984 and 2008, a county within a swing state saw "\$27.8 million more in federal spending than [did] a comparable county in a non-swing and non-core state" (2015b, 137). Hudak (2014) finds this county-level effect meaningfully aggregates to the state level, with swing states receiving in excess of $\$ 1.5$ billion in additional spending during election years.

Though this work has reinvigorated the study of the president's role in the American political system, it leaves unanswered some fundamental questions about presidential particularism. This limitation is a function of the most common object of interest: federal grants. In the stylized congressional context, particularistic behavior often manifests itself in "pork-barrel" spendingwith national receipts reallocated for local use to the benefit of legislators' electoral interests. Presidential influence occurs as individual earmarks and requests are aggregated to the budgetary level — and ultimately implemented by federal agencies. Identification of presidential incentives, together with the presence of strong correlations between those incentives and grant allocation, indicate that presidential influence is both operative and impactful. However, the precise mechanism by which presidential preferences are brought to bear on the distribution of federal spending is difficult to tease out.

The list of possible means of achieving presidential particularism in federal grant allocation is long. As Berry, Burden and Howell (2010) argue, presidents have both "ex ante" and "ex post" means of influencing policy. They are first-movers in the budgetary process and hold formal legislative powers in the presidential veto (Cameron 2000; McCarty 2000). With congressional approval, they may transfer or reprogram funds. They can construct new bureaus and agencies by directive (Howell and Lewis 2002; Lewis 2003), politicize agencies (Lewis 2008), and 
centralize decision making within the White House and Executive Office (Dickinson 1997; Rudalevige 2002). By highlighting these mechanisms, scholars have argued that their empirical findings are the result of a deliberate, systematic effort on the part of presidents and their administrations. However, the critical task of adjudicating between which mechanisms are more or less important is difficult. Each operates at a different stage of the policy-making process and is subject to its own limitations. Of recent work on presidential particularism, only Hudak (2014) investigates these avenues of influence directly, uncovering suggestive evidence that an increase in the number of political appointees within an agency renders them more responsive to the president's electoral interests.

The difficulty associated with analyzing the means of presidential particularism stands in sharp contrast to studies of distributive politics in the legislative realm. For members of Congress (MCs), the mechanism is quite clear: produce a law. Legislation produced can be traced to authors, sponsors, and ultimately "yeas" and "nays." For the president, the distribution of federal spending carries no clear lineage. Federal grant awards do not bear the president's signature. They are not awarded from the oval office. Ultimately, the multiplicity of mechanisms limits what researchers can argue about hypothetical attempts to limit particularistic allocation on the part of the president. That is, if the process by which presidents facilitate the implementation of policy contains a particularistic side effect, it is not clear what remedy scholars could prescribe.

If presidents' electoral incentives are powerful enough to merit harnessing the aforementioned tools, we should expect those incentives to extend beyond domestic spending. Presidents are not merely stewards of federal largesse, they supervise (however, indirectly) the implementation of all public policy. Many of these areas of policy carry equal weight in terms of economic impact. Kriner and Reeves (2015b), for example, highlight particularistic trends in military base closings, disaster declarations, and trade. In our view, the latter-trade—provides an excellent opportunity to address the concerns laid out above. In most cases, presidents have been statutorily required to "proclaim" trade barrier revisions. Though the authorization (and reauthorization) of the RTAA and other trade agreements reflects congressional preferences, trade adjustments via presidential directive represent the revealed preferences of the sitting president. In this way, they offer the same direct linkage afforded by pork-barrel legislation.

Trade adjustments also side step many of the potential concerns associated with isolated analyses of federal grants, since agency problems associated with implementation of tariff rates or NTBs are comparatively minimal. More specifically, whereas both federal grants and trade adjustments are subject to ex ante influence on the part of a multitude of actors, trade adjustments are subject to comparatively minor (even non-existent) influences after they acquire the president's signature. The details of their administration are not left to agents. They are often simple amendments to the existing tariff schedule or quota. This allows us to focus exclusively on incentives (e.g., electoral, partisan, policy) and actors (e.g., legislators, interest groups, voters) that drive presidential behavior. Thus, like any of the unilateral tools identified by past research, the president's observed behavior will be indicative of the influence of other actors.

Moreover, the political salience of trade policies during the latter half of the 20th century is low, especially compared to the height of tariff battles in Congress between 1870 and 1930. Public information on this issue is limited, and its economic impact-though substantial-is often delayed. Thus, it is unlikely the average (or even attentive) voter would be capable of directly connecting marginal changes in the tariff schedule to changes in the prices of commodities. ${ }^{3}$

\footnotetext{
${ }^{3}$ Congressional voting on trade policy often has a clear ideological dimension (Jackman 2001). Yet, Presidents serve a national constituency, and in general, have strong incentives to support free trade (Karol 2007).
} 
Research has also shown that Congress and the Judiciary contest presidential preferences in foreign affairs systematically less often. While this is most apparent in military (Howell, Jackman and Rogowski 2013) and intelligence (Zegart 2011) affairs, presidents' preeminence in foreign policy provides them with the opportunity to act on particularistic incentives.

In short, trade is an ideal place to look for evidence of particularism because the president has direct and observable influence, and opposing political forces in Congress, the Judiciary, and the mass public may be less likely to contest direct action. ${ }^{4} \mathrm{We}$ will describe in more detail the president's authority to revise trade policies as a particularistic tool, and identify the audience for such revisions (key industry interests in states), but first we present a short history of presidential particularism and trade to provide historical context and set the stage for the analysis to come.

\section{PRESIDENTIAL PARTICULARISM AND TRADE: A SHORT HISTORY}

For the Nation's first century, determining policy in the area of international trade had been solely the domain of Congress. Beginning in 1816, with the passage of what is generally considered the nation's first protective tariff (Stathis 2014), Congress began adjusting tariff rates and schedules as a way to help (or hurt) various agricultural and manufacturing interests in their districts or states. Trade policy, therefore, became a prime area of distributive politics in the 19th century, and trade deals often involved intricate logrolls, usually within the majority party and sometimes across parties. These logrolls became increasingly difficult to devise over time, as interests became more numerous and complex and MCs and parties faced more and more demands. As Epstein and O'Halloran note: "The process of building trade legislation item by item can thus lead to a collective dilemma of over-logrolling, similar to the much discussed tragedy of the commons. The end result is that all legislators are made worse off than before" $(1999,223)$.

A complete solution to this dilemma-delegation of tariff-setting authority to the presidentwas not resolved until the early New Deal years, but MCs recognized the problem early on and increasingly so after the Civil War. Congress first took steps in the direction of delegated authority during the Gilded Age, with the passage of the McKinley Tariff in $1890 .{ }^{5}$ In that Act, the president was provided with the discretion to enter into limited reciprocal trade agreements with countries that produced certain items, as a way to secure favorable trade concessions for the United States. The reciprocity clause was eliminated in 1892 by the Wilson-Gorman Tariff Act, but reinstated and expanded to include other eligible items in 1897 by the Dingley Tariff. In addition, the Dingley Tariff also provided the president with the ability to enter into agreements that reduced duties in existing statutes. A change was made again in 1909, with the Payne-Aldrich Tariff Act, in which Congress established maximum and minimum tariff rates

(F'note continued)

However, the peculiarity of the Electoral College also incentivizes them to provide particularistic benefits. So, we argue that after the enactment of liberalizing policies, they are motivated to provide exceptions to key constituencies. Thus, in our view, the ideological character of trade policy does not undercut its nature as a particularistic enterprise-both because presidents (unique) preferences are generally consistent across this matter, and because their position-taking actions relating to large trade deals and legislation can be dissociated from the directives they sign.

4 Another way that presidents might use unilateral directives on trade would be to build a coalition (inside and outside of Congress) for a new major trade law. Viewed in this way, trade adjustments would resemble side payments - or a kind of currency to build a coalition for a statutory enactment. While interesting, and worthy of exploration, such a story is beyond the scope of our analysis.

5 The tariff history in this section is based on Wolman (1992), Goldstein (1993), O'Halloran (1994), and Irwin (Irwin 2005; Irwin 2011). 
and delegated administration (and application) of the appropriate rates to the president. The president was also allowed to create the Tariff Board, to improve his informational capacity. In 1913, with the Underwood Tariff Act, the president was provided with another grant of authority, this time to negotiate comprehensive trade agreements, not just pacts over a limited set of specified items.

With the passage of the Revenue Act of 1916, tariff politics entered a new phase. The Revenue Act established the Nation's first permanent federal income tax, which led to a substantial decline over time in the percentage of federal revenues attributable to custom duties. It also included an anti-dumping provision, to protect domestic industries, and created a Tariff Commission to help establish "objective" tariff rates. In 1921, the Emergency Tariff Act shifted the enforcement of the 1916 Act's anti-dumping provision from the courts to the executive agencies, and adjusted the remedy from fines and possible imprisonment to higher import duties. The following year, in 1922, the Fordney-McCumber Tariff Act expanded the antidumping and anti-discrimination parameters of the previous two acts, but perhaps more importantly, provided the president with the discretion to raise or lower duties (by as much as 50 percent) that were fixed in statute by proclamation (upon an equalization-of-cost-ofproduction recommendation by the Tariff Commission). The highly protectionist SmootHawley Tariff Act of 1930 carried over the "flexible tariff provision" of the 1922 Act, thus maintaining the president's proclamatory power to adjust rates fixed in statute, once again per the recommendations of the Tariff Commission.

Finally, in 1934, with the RTAA, congressional delegation of trade authority to the president was effectively complete. The new Democratic majority took aim on the overly protectionist features of Smoot-Hawley and sought to solve the collective dilemma of over-logrolling once and for all. As O'Halloran writes: "Instead of giving the president limited authority to increase or decrease certain tariffs set by Congress either through reciprocal trade concessions or through objective criteria, the president could now enter into commercial agreements and change any rate by proclamation" (1994, 85-6). Moreover, he could do this on his own, without relying on the actions or attention of an external agent (like the Tariff Commission).

In delegating authority for international trade to the president, the Congress also stipulated that such delegation would be renewed regularly. And RTAA extensions were frequent (every two to four years) and sometimes contentious events for the next three decades. The politics of these extensions usually involved Congress working to ensure that domestic industries had input in decision-making processes and that oversight mechanisms were created such that information from the executive was readily reported and shared. In 1962, Congress passed the Trade Expansion Act, which broadened the president's trade authority by allowing him to negotiate multilateral (as well as bilateral) agreements, while also including additional safeguards to protect domestic industry. Finally, in 1974, Congress passed the Trade Reform Act, which provided the president with the authority to negotiate arrangements to harmonize, reduce, or eliminate trade barriers (both tariffs and NTBs). However, in exchange for this delegation, which would essentially allow the president to alter various domestic codes, Congress required that such international agreements (going forward) receive legislative approval, and set up a new institutional system-known as "fast track"-that would allow the new presidentialcongressional system to work. Such a system included (among other things) a pre-negotiation period, which would allow interested parties to provide input; further protections and safeguards for domestic industries; and a short window by which Congress could act on a presidential agreement (and only by an up-or-down vote).

The "modern" era of trade agreements, then, was first marked by the RTAA in 1934 and more recently by the Trade Reform Act of 1974. In the former, the president was provided 
with wide proclamatory discretion regarding the adjustment of tariff rates and schedules. In the latter, Congress further expanded the president's authority in the realm of trade, but also provided itself with a formal role in the monitoring of executive action. More recent trade laws have largely been adjustments vis-à-vis the 1974 Act, based on changing world conditions.

\section{UNDERSTANDING PRESIDENTIAL TRADE AUTHORITY}

How might we understand the president's authority to revise trade policies as a particularistic tool? Answers to this question follow from comparing and contrasting trade barriers with federal grants. First, unlike redistribution via grant (Cox and McCubbins 1986; Londregan and Dixit 1996), tariffs and NTBs cut across traditional interest groups. The protection of a particular commodity benefits both labor and management. Second, by influencing a single commodity, they impose diffuse costs on consumers while providing an immediate benefit to American producers. Similarly, grants impose diffuse costs (via taxation) in order to provide localized benefits. Third, the use of trade barriers is not subject to an obvious resource constraint-in that, they actually raise government revenue. Given this, we argue that while trade policies will likely reflect the particularistic imperatives identified by Kriner and Reeves (Kriner and Reeves 2015a; Kriner and Reeves 2015b) and others, with the key modification that co-partisan legislator's should not benefit from the President's discretion in this area.

Trade policies are linked to a range of domestic industries and are often broad in scope. Even provisions that target a specific industry will affect producers beyond self-contained geographic units (districts and even states) - in addition to cutting across traditional interest group fault lines. Thus, relative to grants, which can be geographically targeted, trade barriers are comparatively blunt instruments. Yet, grants are less unilateral in orientation and require greater cross-institutional collaboration. Thus, in exchange for unilateral discretion, the president wields a less precise instrument. To enter the world of metaphors, grants might be thought of as "sniper rifles," whereas trade barriers are closer to "shotguns." We argue variance in downrange groupings renders the latter ineffective at aiding the electoral fortunes of presidential co-partisans. Grants, on the other hand, are appropriate instruments for targeting narrowly defined geographic areas (like House districts) and thus, are suitable for helping co-partisans in Congress.

Extending the study of particularism to trade policies also raises additional questions about the interaction of the instruments. That is, if the president has a variety of tools that could be used to satisfy a particularistic imperative, is it reasonable to assume those tools could be substitutes? More specifically, are federal grants and tariff barriers exchangeable? Here again, it is important to highlight key differences between the two. Trade barriers-despite their bluntness - serve as an effective mechanism to satisfy the needs of particular kinds of "attentive publics" (Arnold 1990), namely key industry interests affected by international competition and trade. ${ }^{6}$ As Kriner and Reeves note: "presidents have ... routinely provided relief from foreign competition for select industries, particularly those with considerable political clout" (2015b, 53).

\footnotetext{
${ }^{6}$ While Arnold (1990, 64-5) spoke of "attentive publics"-citizens who are aware of issues, understand alternatives, and have clear preferences -in the context of congressional action, the same sort of "electoral connection" logic can easily be extended to the president (see e.g., Kriner and Reeves 2015a; Kriner and Reeves 2015b).
} 
This mechanism is distinct from those identified in studies of federal spending, in which scholars argue (implicitly or explicitly) that citizens vote based upon the economic conditions in their local community (see Kriner and Reeves 2012 for a summary of this literature). As grants directly improve local economic outcomes, voters will be more likely to perceive presidents favorably as a result - and reward them at the ballot box. Though trade barriers may trickledown to the citizen level, we argue that their primary audience will be key industries in stateswhich play close attention to the administration's willingness to protect them from foreign competition, and can marshal the necessary resources to support or oppose the president come election time. These differences underscore a basic point: trade barriers and grants-despite their usefulness for redistribution-serve different audiences. This means their impact is not exchangeable and-as a result—we do not expect presidents use them as substitutes.

Finally, as previous work largely demonstrates, there is a key temporal aspect to presidents' redistributive policies. Thus, if presidents indeed use such trade authority for electoral benefit, we would expect adjustments to align with presidential election cycles. That is, we should be more likely to observe protectionist revisions during presidential election years, as those years provide the clearest opportunity for satisfying presidents' assumed electoral goals.

\section{PROTECTIONISM IN UNILATERAL ORDERS}

The study of presidential particularism in the area of trade policy offers a unique opportunity to identify politically motivated changes. Unlike the allocation of federal grants, trade modifications bear the president's signature—as such, they are comparatively "unilateral."7 Moreover, though there is some variance in the type of directive used to effectuate these changes, presidents have been statutorily required to publish changes in the Federal Register. ${ }^{8}$ For this reason, they can be analyzed across a long time-series-whereas analyses based on grant allocations and the Federal Assistance Award Data System are typically restricted to the 1970s and beyond. Our data set contains 345 presidential directives issued between 1917 and 2006.

The event of theoretical interest is a unilateral change in trade policy made by a president. This is most commonly achieved by proclamation, but in the data collection process, we discovered a handful of executive orders (3) and memoranda (16) that produced similar changes. For sources, we use Rottinghaus and Lim's (2009) database of presidential proclamations, executive orders available at Wooley and Peter's American Presidency Project website, and presidential memoranda collected by Lowande (2014). ${ }^{9}$ This data gathering produced 630 trade-related presidential directives. We then imposed a few additional criteria for inclusion. First, several of these trade-related directives do not prescribe policy changes; instead, they delegate policy-making authority to a bureaucratic agent. Since these directives do not contain the changes themselves, they are not included in the analysis. ${ }^{10}$ Second, many other directives are country specific, rather than industry specific. That is, they are direct responses to policies

\footnotetext{
${ }^{7}$ This is not to say that they are completely unilateral. Most of the directives contained in our data set describe some recommendation or investigatory process undertaken by an administrative agency. As we indicated in second section, the orders are not free of ex ante influence. The key value-added from previous analyses, however, is that the policy outcome is implemented by the president's signature-rather than the promulgation of a rule or the administration of a new program.

${ }^{8}$ For example, the Trade Act of 1974 (P.L. 93-618) provided that the President may "proclaim" modifications, which must-like executive orders_-be catalogued and published (Mayer 2001).

9 The American Presidency Project: http://www.presidency.ucsb.edu/

${ }^{10}$ Note that there were 27 trade-related delegation orders. Only three of these relate to tariffs on particular industries, and thus would have been included if a particular direction could be identified.
} 
TABLE $1 \quad$ Protectionism in Unilateral Directives, 1917-2006

\begin{tabular}{lccc}
\hline Variables & (a) & (b) & (c) \\
\hline Presidential election year & $0.68^{*}$ & $0.66^{*}$ & $2.86^{* * *}$ \\
& $(0.35)$ & $(0.36)$ & $(0.96)$ \\
Midterm election year & $-0.52^{*}$ & $-0.54^{*}$ & $-0.63^{*}$ \\
& $(0.31)$ & $(0.32)$ & $(0.32)$ \\
Divided government & $-0.91^{*}$ & $-0.96^{*}$ & $-0.98^{*}$ \\
& $(0.51)$ & $(0.52)$ & $(0.53)$ \\
Unemployment & -0.04 & -0.02 & $-0.11^{*}$ \\
& $(0.05)$ & $(0.06)$ & $(0.07)$ \\
War & $-2.22^{* *}$ & $-2.27 * *$ & $-2.77^{* * *}$ \\
& $(0.88)$ & $(0.89)$ & $(0.96)$ \\
Post-RTAA & & 0.92 & 0.24 \\
& & $(1.22)$ & $(1.20)$ \\
Post-RTAA $\times$ presidential election & & & $-2.26^{* * *}$ \\
Post-1974 Act & & $-13.37^{* * *}$ & $-12.53^{* * *}$ \\
Post-1974 Act $\times$ presidential election & & $(1.02)$ & $(1.24)$ \\
Constant & & & -0.92 \\
Pseudo- $R^{2}$ & 0.61 & $12.93^{* * * *}$ & $(0.82)$ \\
Log pseudolikelihood & $(0.51)$ & $(1.79)$ & $\left(1.75^{* * *}\right.$ \\
$N$ & 0.17 & 0.17 & 0.19 \\
& -197.66 & -196.65 & -192.34 \\
\hline
\end{tabular}

Note: Dependent variable: whether directive raised tariffs; logit coefficients with robust standard errors in parentheses; presidential fixed effects omitted.

RTAA $=$ Reciprocal Trade Agreements Act.

$* \mathrm{p}<0.1, * * \mathrm{p}<0.05, * * * \mathrm{p}<0.01$, two-tailed tests.

enacted by other nations. We omit these directives for two reasons. Linking presidential directives to elections requires identifying beneficiaries-a task muddied by country-specific responses. On the one hand, all competing domestic producers may benefit from trade barriers such as these, but there may be some "target" beneficiary that motivated the change. Since this suggests that some cases of particularism will be concealed, we believe this biases our analysis toward null findings. Moreover, it is likely that a separate data generating process governs these observations. That is, the president's discretion in this area is constrained by the actions of foreign political actors, who enact the trade barriers that precipitate a reciprocal response. Thus, our data set contains proclamations, executive orders, and memoranda that explicitly amend trade policies by targeting specific industries-either to protect domestic producers or promote trade liberalization.

As an initial descriptive exercise, we code whether or not these orders were protectionist (1) or universalistic (0), to investigate whether their content varies in a way consistent with presidential particularism. Recall that we expect presidents to strategically allocate protectionist orders to aid their electoral fortunes. ${ }^{11}$ Trade barriers artificially inflate the prices of goods, allowing domestically produced commodities to remain competitive in the US market. In effect, they provide a localized benefit to those producers, with a collective cost (higher prices)

\footnotetext{
${ }^{11}$ Note that, in our primary analysis, we also test whether presidents allocate orders to benefit co-partisans in the House and Senate. However, as our earlier discussion indicates, industry-wide benefits are likely too imprecise to be targeted to aid particular co-partisan legislators.
} 


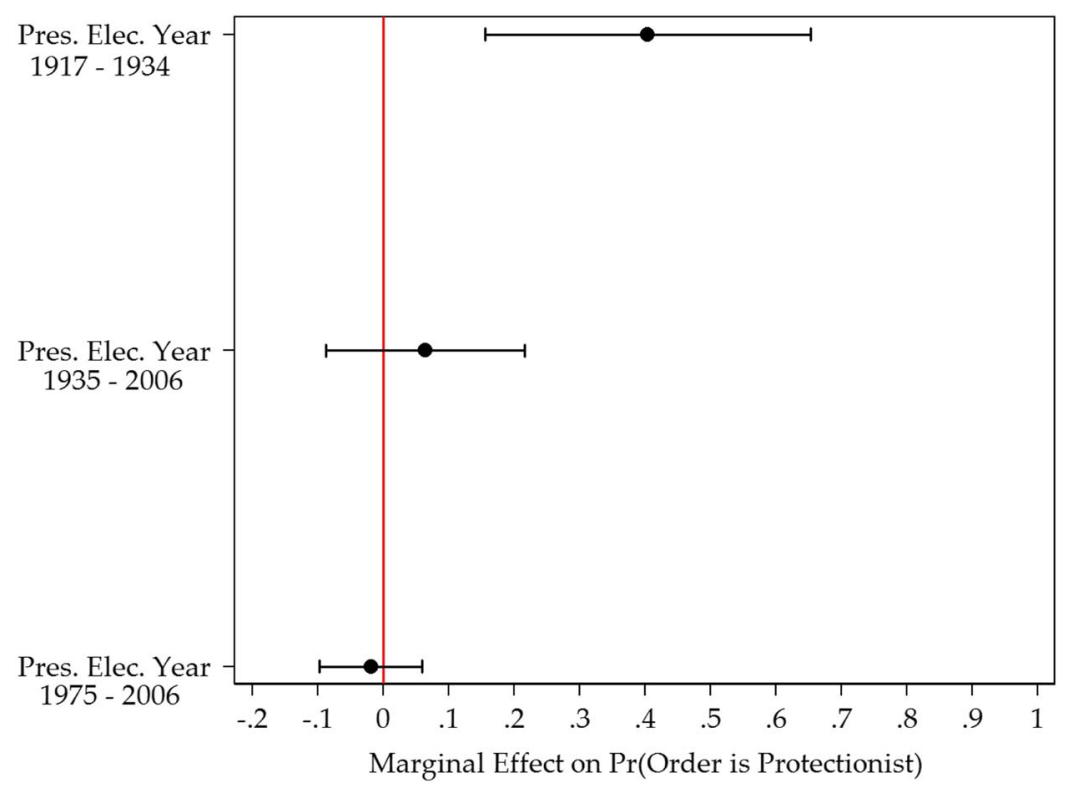

Fig. 1. Protectionism in unilateral directives, by period

diffused at the national level. Therefore, we might expect to see particularistic directives to be concentrated in presidential election years.

In Table 1, we estimate whether an order was protectionist on an indicator variable for presidential election years. ${ }^{12}$ The unit of analysis is a unilateral directive issued between 1917 and 2006. To account for the possibility that the result may be a function of the non-random distribution of directives, we include divided government (coded " 1 " if either chamber of Congress is controlled by the opposition), unemployment rate, ${ }^{13}$ an indicator for major war years, ${ }^{14}$ and presidential fixed effects. In addition, since the RTAA of 1934 and Trade Act of 1974 substantially adjusted the president's discretion to alter tariff schedules and NTBs, we include appropriate indicator variables - the first, coded " 1 " for all years post-1934, the second, coded "1" for all years post-1974. To explore whether these dramatic statutory shifts influenced patterns in presidential protectionism, we also interact these indicators with presidential election years. ${ }^{15}$

In keeping with our general expectation, directives are more likely to be protectionist in presidential election years. Roughly 55 percent of the directives in our data set are protectionist; however, in general, those issued during presidential election years are more likely to be protectionist. In column (a) of Table 1, a presidential election year results in a 13 percentage point increase in the probability an order is protectionist. After controlling for the enactment of the RTAA and 1974 Act in column (b), the magnitude of this effect remains the same. We find,

\footnotetext{
12 An alternative approach might be to use to the proportion of orders that were protectionist in any given year as a dependent variable. In general, replication of the results in Table 1 produces coefficients that are less precisely estimated (given the reduction in statistical power), however, in the full interactive model, the presidential election year result remains substantively and statistically significant.

13 Source: US Department of Labor, Bureau of Labor Statistics. For missing years early in the time-series, we assume missing values follow a linear trend to next available observation.

${ }^{14}$ Coded "1" in years in which the United States was engaged in World War I or World War II.

15 A table of summary statistics for each variable is included in the Online Appendix.
} 
however, that this effect appears to be largely driven by years prior to the enactment of the RTAA. More specifically, in model (c), we allow the effect of presidential election years to vary based on the RTAA and 1974 Act by interacting presidential election years with each enactment. The results suggest that the RTAA dampened the tendency for orders to be protectionist during presidential election years, whereas the 1974 Act had little additive impact. Figure 1, which provides the marginal changes in probability by enactment period, illustrates this. Though a broader consideration of the effect of these statutory changes is beyond the scope of this study, these results suggest that it may be more difficult to observe evidence of presidential particularism in trade policies during later periods. This is important, because the analysis that we present in the following sections relies on orders from 1986 through 2006, which may bias against empirical support for our hypothesis.

The estimated relationships are also distinct from trends in protectionism during midterm elections. In fact, the estimated relationship is slightly negative, implying that protectionism is less likely in these directives. There is also some evidence that orders are less likely to be protectionist under divided government. This suggests that an opposition-controlled Congress may constrain the president's ability to enact revisions. Overall, these results suggest that particularistic trends among trade orders warrant further investigation. If, as others have argued (e.g., Karol 2007), presidents have incentives to promote free trade, there are few plausible alternative explanations for why they would concentrate protectionist actions during election years. ${ }^{16}$ However, to investigate this further, we must shift our empirical focus to state-level benefits derived from unilateral changes in trade policy. If presidents use trade protection as a "particularistic" tool, it is not enough to observe that these orders tend to be concentrated near election years-we must determine whether their allocation of benefits follows the electoral incentives of the president.

\section{STATE-LEVEL ANALYSIS: DATA AND EMPIRICAL STRATEGY}

In the early 20th century, presidential directives were systematically more likely to enact protectionist trade adjustments in presidential election years. By contrast, we found little evidence that elections affect the nature of unilateral trade adjustments in the post-RTAA era. We further investigate these findings by analyzing which states benefit from protective orders between 1986 and 2006. Following Kriner and Reeves (2015b), we are primarily interested in detecting electoral calculations that may affect the decision to enact federal trade adjustments. Consequently, we test whether or not presidents use their discretion to benefit (1) presidential "swing" states, (2) presidential "hostile" states, (3) states with vulnerable senators of the president's party, and (4) states with a large proportion of vulnerable House members from the president's party. Finally, we consider the conditioning effect of election cycles on each of these explanatory variables. Below we discuss the extensive data and conditional empirical strategy employed to test these expectations.

Our dependent variable, State Protected, is an indicator variable that identifies which states were the most affected by a protectionist trade adjustment. ${ }^{17}$ To generate this variable, we first

\footnotetext{
${ }^{16}$ For a similar argument about presidents in a broader comparative context, see Nielson (2003), who contends that delegation to presidents promotes liberalization of trade policies.

17 While we restrict our analysis to protectionist orders, we acknowledge the political benefits that may follow from lowering a trade barrier. In December 2003, for example, President Bush lowered tariffs on steel as export industries in Florida and Michigan were threatened by tariff retaliation from the European Union (Stevenson and Becker 2003). Protectionism, however, provides the clearest case of "particularism." Though future work might tie "universalistic," or liberalizing, orders to the set of states that may directly benefit from them, this would
} 
code the direction of each unilateral trade adjustment between 1986 and 2006. Presidential actions were coded either as protectionist or not-protectionist, where protectionist actions restricted foreign imports through tariffs and NTBs and non-protectionist actions generally liberalized trade arrangements. Next, we identified the industry (or industries) affected by a given unilateral action, and code the five states most likely to be affected by protectionist trade policy for that specific industry. ${ }^{18}$ In general, we relied upon official government resources to code the top five states affected by a presidential trade adjustment. Because these coding decisions are specific to a particular industry in a particular year, we relegate additional information on the construction of this variable to the Online Appendix - which provides a full list of data sources used to identify the states most affected by individual trade adjustments. ${ }^{19}$ The final product of these data efforts is a dichotomous variable, which is coded " 1 " if a state is among the top five affected by a unilaterally implemented protectionist adjustment in a given year and "0" otherwise.

The most obvious place we might detect particularism in trade politics is among the most competitive states in presidential electoral politics. Our first electoral predictor of interest is thus Swing States, a binary indicator for states that were highly contested in recent presidential elections. If we believe that presidents target vital business interests with trade adjustments, swing states provide opportunities to shore up their vote share. Following Kriner and Reeves (2015b), we identify swing states as those states in which the losing candidate averaged 45 percent or more of the two-party vote over the past three presidential election cycles. These data were obtained from The American Presidency Project.

By contrast, presidents may be unlikely to provide particularistic benefits to Hostile States, as these states are unlikely to generate electoral support for the president. We again follow Kriner and Reeves (2015b) by defining "hostile" states as those states that the president's party received, on average, $<45$ percent of the two-party presidential vote share in the previous three election cycles. Coupled with the Swing State variable, our Hostile State variable creates a third, mutually exclusive baseline category: "core" states in which the president's party received, on average, $>55$ percent of the two-party vote over the last three contests.

To advance his agenda, the president may also adjust trade policy to benefit congressional co-partisans. Unilateral trade adjustments may also be used to satisfy industry leaders who are in a position to support like-minded legislators. By this logic, presidents may target states with vulnerable co-partisans as a complementary strategy in distributive politics. Testing this conjecture requires the construction of two additional variables. First, we use electoral data provided by the Database on Ideology, Money in Politics, and Elections to create a Senate Co-Partisan Vulnerability measure (Bonica 2013). This is a dichotomous measure of whether or not an incumbent senator from the president's party received up to 55 percent of the two-party vote in the most recent election cycle. Second, we use Gary Jacobson's House election data

(F'note continued)

require additional (potentially problematic) judgments about the intended beneficiary. Liberalization of trade benefits both industries (e.g., restaurants) and consumers (e.g., grocery shoppers) in a way that significantly complicates the geographic coding procedures necessary to execute a state-level analysis.

${ }_{18}$ This measure typically takes production quantity as an indication of economic interest. We use the top five states because the values used to identify those states most affected by a particular industry tend to be clustered among a handful of states (i.e., the fourth most affected state was not very different from the second). But as a robustness check, we construct a variable for the top ten states affected and rerun our statistical models. Our results remain robust to this alternative specification.

${ }^{19}$ Note that the data in the Online Appendix include both protectionist and non-protectionist actions. In general, no industry receives more than a handful of protectionist orders in our time-series, alleviating possible outlier effects. 
to construct the proportion of vulnerable presidential co-partisans in each state, where vulnerability is measured as winning in the most recent congressional election cycle with no $>55$ percent of the two-party vote share..$^{20}$ This provides our House Co-Partisan Vulnerability variable, which is bounded between 0 and 1 .

Finally, we control for potentially confounding "substitution effects" of federal grant allocations to these states. To avoid biasing the inferences drawn from our electoral variables, we use data from Kriner and Reeves (2015b) for the logged amount of federal dollars each state received in each year for the duration of our time-series. These data were originally compiled using Consolidated Federal Funds Reports on each federal program. ${ }^{21}$ As we have argued, there is good reason to believe that these tools may not be simple substitutes, but it is important to test this empirically.

If electoral calculations drive presidential trade adjustments, the effect of these variables should be particularly pronounced in crucial moments throughout the general election campaign. To capture this electoral conditioning effect, we interact each of our explanatory variables with a dichotomous indicator for relevant election years. Hostile States and Swing States are interacted with Presidential Election Year. Our House Co-Partisan Vulnerability measure is interacted with an indicator for a Midterm Election Year, and our Senate variable is interacted with a state-specific indicator for Senate Election Year. ${ }^{22}$ We estimate the electoral influence of presidential trade revisions with a logistic regression model.

\section{STATE-LEVEL ANALYSIS: RESULTS}

Our results suggest that the use of unilateral trade adjustments is conditioned by presidential election cycles. States that are electorally valuable to the president are significantly more likely to have their industries protected in presidential election years. Surprisingly, this conditional affect also increases the probability of receiving protectionist benefits for states that consistently support the opposing party. By contrast, we find no evidence that protectionist adjustments have been used strategically to assist co-partisans in the House or Senate. Our full results are provided in Table $2 .{ }^{23}$ We provide marginal effects plots for the presidential interactions in Figure 2, and predicted probabilities are reported in the Online Appendix (Figure A2). All results include standard errors clustered by state.

In non-presidential election years, when the president provides protection to industries through executive action, his actions benefit states irrespective of their electoral value. Specifically, we find that hostile states and swing states are no more likely to receive protectionist trade adjustment than presidents' core states. The marginal effect on the probability of receiving protectionist benefits is 0.06 , but we cannot reject the null hypothesis of no effect. Swing State results are similar, with a marginal effect of $0.11(p>0.1)$.

In presidential election years, we find dramatically different results. States are significantly more likely to receive presidential protection when their electoral value is most salient. More specifically, the predicted probability that Swing States receive protection from presidential directives increases from effectively 0 in non-presidential election years to 0.6 in presidential

\footnotetext{
${ }^{20}$ We thank Jamie Carson for providing these data.

21 We thank Douglas Kriner and Andrew Reeves for aggregating and providing these data.

22 Table A2, in the Online Appendix, provides summary statistics for each of these variables.

${ }^{23}$ It is possible that states with more diverse economies will, by the nature of their blended production capacity, be more likely to benefit from protectionist orders-even if they are not explicitly targeted by the president. To address this concern, we coded and controlled for the 13 most economically diverse states according to five distinct indices (i.e., one entropy index, two ogive indices, and two national average indices; Tran 2011). Both columns in Table 2 are robust to this specification. Our presidential interactions provide similar levels of statistical significance and marginal effect size.
} 
TABLE 2 Protecting State Industries, 1986-2006

\begin{tabular}{|c|c|c|}
\hline Variables & (a) & (b) \\
\hline Hostile state & $\begin{array}{c}1.38 \\
(0.90)\end{array}$ & $\begin{array}{c}1.37 \\
(0.88)\end{array}$ \\
\hline Presidential election year $\times$ hostile state & $\begin{array}{l}13.01 * * * \\
(1.07)\end{array}$ & $\begin{array}{l}11.76 * * * \\
(1.03)\end{array}$ \\
\hline Swing state & $\begin{array}{l}1.70^{*} \\
(1.00)\end{array}$ & $\begin{array}{l}1.72 * \\
(0.98)\end{array}$ \\
\hline Presidential election year $\times$ swing state & $\begin{array}{l}11.95 * * * \\
(1.20)\end{array}$ & $\begin{array}{l}10.68 * * * \\
(1.19)\end{array}$ \\
\hline House co-partisans vulnerable & & $\begin{array}{c}0.98 \\
(1.03)\end{array}$ \\
\hline House co-partisans vulnerable $\times$ midterm election year & & $\begin{array}{c}-1.29 \\
(1.64)\end{array}$ \\
\hline Senate co-partisan vulnerable & & $\begin{array}{l}-0.6 \\
(0.36)\end{array}$ \\
\hline Senate co-partisan vulnerable $\times$ senate election year & & $\begin{array}{c}0.12 \\
(0.66)\end{array}$ \\
\hline Midterm election year & & $\begin{array}{l}0.91 * * \\
(0.44)\end{array}$ \\
\hline Senate election year & & $\begin{array}{c}-0.61 \\
(0.51)\end{array}$ \\
\hline Presidential election year & $\begin{array}{c}-12.84 * * * \\
(1.01)\end{array}$ & $\begin{array}{c}-11.06 * * * \\
(0.99)\end{array}$ \\
\hline Federal grants (logged) & $\begin{array}{c}0.03 \\
(0.27)\end{array}$ & $\begin{array}{c}0.07 \\
(0.28)\end{array}$ \\
\hline Constant & $\begin{array}{c}-5.10 \\
(6.23)\end{array}$ & $\begin{array}{c}-5.97 \\
(6.40)\end{array}$ \\
\hline Pseudo- $R^{2}$ & 0.02 & 0.04 \\
\hline Log pseudolikelihood & -190.92 & -186.73 \\
\hline$N$ & 1050 & 1050 \\
\hline
\end{tabular}

Note: Dependent variable: state protected by unilateral directive $(0,1)$; logit coefficients with robust standard errors, clustered by state, in parentheses.

$* \mathrm{p}<0.1, * * \mathrm{p}<0.05, * * * \mathrm{p}<0.01$, two-tailed tests.

election years. ${ }^{24}$ These results are also consistent across both models, and the marginal effects for these variables in the full model are reported in Figure 2.

Counter to our expectations, we also find statistically significant results for Hostile States. While the magnitude of the effect is significantly lower, our model estimates a 0.3 increase in the marginal change in probability of receiving presidential protection. We can think of several possible motivations for the preference given to Hostile States. First, it is possible that the president attempts to move a Hostile State into contention early in the election cycle through trade adjustments. Alternatively, he may try to mute industry opposition capable of mobilizing electoral support for his competition. By providing benefits to the opposing party's most loyal states, the president may force his opponents to invest resources they might otherwise pour into swing states. Ultimately, this finding suggests that presidential targeting of trade adjustments differ from that of federal grants-though the current results do not allow us to adjudicate between alternative explanations.

\footnotetext{
${ }^{24}$ These results are robust to the exclusion of lame-duck presidential election years. That is, when we include only presidential election years in which a sitting president was on the ballot, the interactive effect remains positive and substantively significant in the expected direction. Thus, we find no support for the notion that lameduck and incumbent presidents behave differently. This could be because a lame-duck president seeks to help his would-be, co-partisan successor, and/or protect his policy legacy, but this is purely speculative-and additional inquiry is needed to better understand the motivations in play.
} 


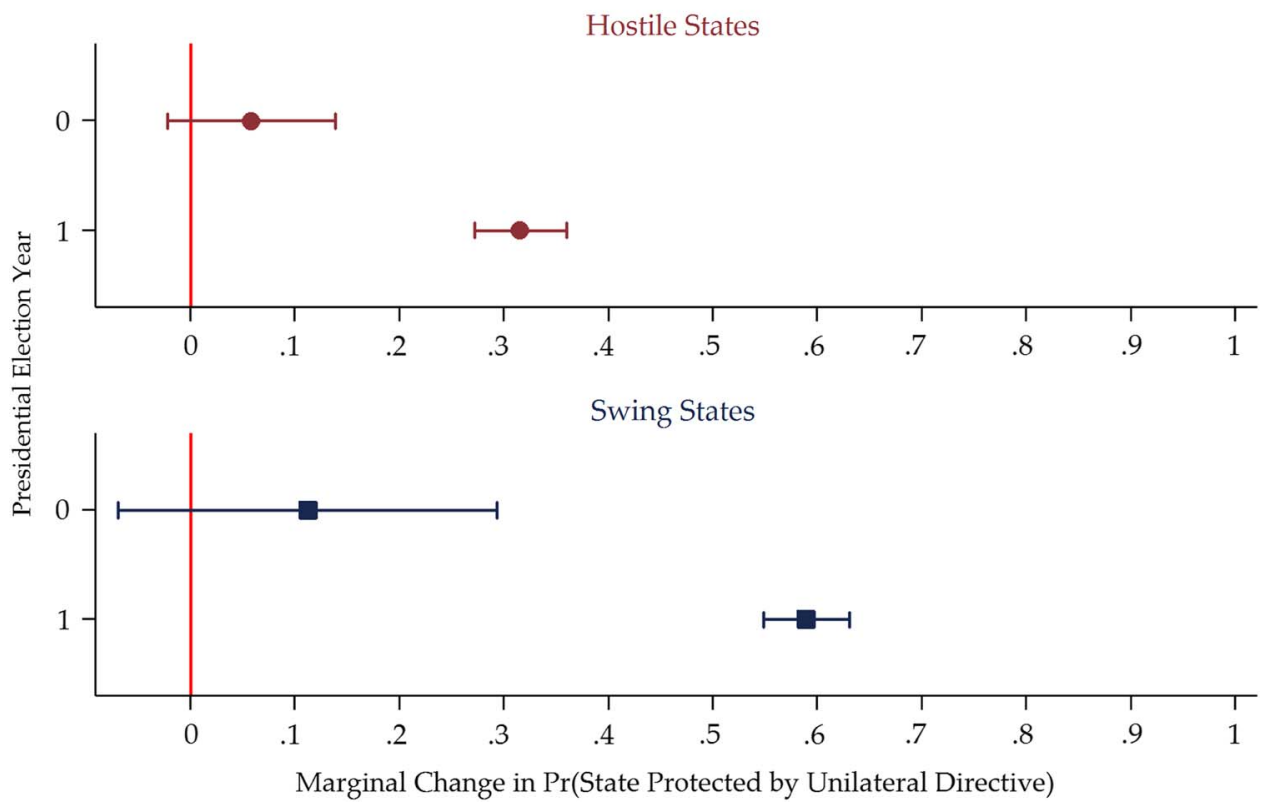

Fig. 2. Protecting state industries, 1986-2006

Moreover, in contrast to existing work, we find no support for a complementary, congressional strategy of distributive benefits. The marginal change in probability for states with vulnerable legislators is consistently indistinguishable from 0 . Simply put, the president's co-partisans in both the House and Senate do not appear to benefit from the president's discretion over trade barriers. In fact, we find that states without vulnerable House co-partisans experience a small (0.04) increase in the probability of protection during midterm election years, but we have less confidence rejecting the null $(\mathrm{p}<0.1$, with a 95 percent confidence interval of $[-0.01,0.09])$.

While the coefficient on presidential election years appears to be strong and in the opposite direction of our descriptive results, the marginal change in probability for this variable indicates that core states are less likely to receive protection in presidential election years than other years-but the effect size remains effectively 0 . Simply put, core states almost never receive protection from unilateral directives. Finally, we find no substitution effects for federal grant allocation in our models. This may suggest that grant allocations and trade adjustments are indeed tools used for distinct political goals, but we hesitate to interpret these null findings further.

In sum, our results suggest that presidential particularism in the area of trade policy is a conditional phenomenon. Presidents generally do not appear to be electorally motivated when they issue trade adjustments, but the probability that a state benefits from the president's discretionary authority over trade increases dramatically if (a) the state is electorally valuable to the president and (b) it is a presidential election year. This finding is consistent with a growing literature on presidential particularism.

\section{CONCLUSION}

In the American political system, the president's influence touches nearly all areas of public policy. In the pursuit of electoral gain, it is conceivable that presidents would use this influence to strategically distribute government benefits. This basic point is as old as presidential systems 
themselves, but recent work has found that—in the American context-it may explain variation in federal spending. There is little reason to believe that the particularistic imperative should be confined exclusively to this area. We have found preliminary - but no less compelling-evidence that presidents use protectionist actions to advance their political objectives. This suggests that presidents' electoral incentives extend into other areas of policy. Moreover, it shows that an important area of international relations may be determined, in part, by the domestic politics of presidential election cycles.

While we find that trade adjustments may follow a particularistic imperative, it is important to underscore the differences (in both impact and otherwise) between them and federal grants. First, unlike federal grants, the institutional steps of the policy-making process for trade policy revision are clear and comparatively unilateral. That is, the mediating effects associated with agency problems in the bureaucracy, as well as the continued influence of Congress in a multi-stage institutional process, means that the empirical relationship between presidential preferences and grant allocations may be far more complicated than the correlations uncovered by past work. Trade directives side step those agency problems somewhat, by bearing the president's signature (and thus, representing his revealed preferences). Moreover, trade adjustments may be a categorically different distributive benefit. They are far less targeted, in that they affect entire industries-which are not confined to states, let alone congressional districts. Their impact provides a different kind of material benefit, with indirect benefits to the larger political units affected. Put simply, trade adjustment is a more blunt tool—despite the fact that it is often under the direct control of the president.

Our findings also point to additional avenues of research. First, our state-level analysis considered a relatively recent period in the history of US trade, during which liberalization was the dominant paradigm. The president's discretion over trade policy dates to the end of the 19th century, suggesting that a historical extension of this analysis could provide more precise and intriguing estimates of the president's particularism in the area of trade. Second, though we found evidence of particularism, our results do not merely replicate the findings of past work in a new policy area. Importantly, we do not find that presidents use tariff schedules or NTBs to reward core states. This suggests that the president may possess a "particularistic toolkit," and that different policy tools may be more or less appropriate given specific electoral or party needs. Both possibilities highlight the importance of trade policy in understanding the scope of the particularistic president.

\section{REFERENCES}

Arnold, R. Douglas. 1990. The Logic of Congressional Action. New Haven, CT: Yale University Press. Berry, Christopher, Barry Burden, and William Howell. 2010. 'The President and the Distribution of Federal Spending'. American Political Science Review 104(4):783-99.

Bonica, Adam. 2013. Database on Ideology, Money in Politics, and Elections: Public Version 1.0 [Computer file]. Stanford, CA: Stanford University Libraries.

Cameron, Charles. 2000. Veto Bargaining: Presidents and the Politics of Negative Power. Cambridge: Cambridge University Press.

Cox, Gary W., and Matthew D. McCubbins. 1986. 'Electoral Politics as a Redistributive Game'. The Journal of Politics 48(2):370-89.

Dickinson, Matthew. 1997. Bitter Harvest: FDR, the New Deal, and the Expansion of the Presidential Branch. Cambridge: Cambridge University Press.

Epstein, David, and Sharyn O'Halloran. 1999. Delegating Powers: A Transaction Cost Politics Approach to Policy Making Under Separate Powers. Cambridge: Cambridge University Press. 
Galvin, Daniel. 2010. Presidential Party Building: Dwight D. Eisenhower to George W. Bush. Princeton, NJ: Princeton University Press.

Goldstein, Judith. 1993. Ideas, Interests, and American Trade Policy. Ithaca, NY: Cornell University Press.

Howell, William, and David E. Lewis. 2002. ‘Agencies by Presidential Design'. Journal of Politics 64(4):1095-114.

Howell, William, Saul P. Jackman, and Jon C. Rogowski. 2013. The Wartime President: Executive Influence and the Nationalizing Politics of Threat. Chicago, IL: University of Chicago Press.

Hudak, John. 2014. Presidential Pork: White House Influence Over the Distribution of Federal Grants. Washington, DC: Brookings Institution Press.

Irwin, Douglas A. 2005. 'The Rise of U.S. Antidumping Activity in Historical Perspective'. The World Economy 28(2):651-88.

Irwin, Douglas A. 2011. Peddling Protectionism: Smoot-Hawley and the Great Depression. Princeton, NJ: Princeton University Press.

Jackman, S. 2001. 'Multidimensional Analysis of Roll Call Data via Bayesian Simulation: Identification, Estimation, Inference, and Model Checking'. Political Analysis 9(3):227-41.

Karol, David. 2007. 'Does Constituency Size Affect Elected Officials' Trade Policy Preferences?'. Journal of Politics 69(2):483-94.

Kriner, Douglas L., and Andrew Reeves. 2012. 'The Influence of Federal Spending on Presidential Elections'. American Political Science Review 106(2):348-66.

Kriner, Douglas L., and Andrew Reeves. 2015a. 'Presidential Particularism and Divide-the-Dollar Politics'. American Political Science Review 109(1):155-71.

Kriner, Douglas L., and Andrew Reeves. 2015b. The Particularistic President: Executive Branch Politics and Political Inequality. Cambridge: Cambridge University Press.

Lewis, David E. 2003. Presidents and the Politics of Agency Design. Stanford, CA: Stanford University Press.

Lewis, David E. 2008. The Politics of Presidential Appointments. Princeton, NJ: Princeton University Press.

Londregan, J., and A. Dixit. 1996. 'The determinants of success of special interests in redistributive politics'. The Journal of Politics 58(4):1132-155.

Lowande, Kenneth. 2014. 'After the Orders: Presidential Memoranda and Unilateral Action'. Presidential Studies Quarterly 44(4):724-41.

Mayer, Kenneth A. 2001. With the Stroke of a Pen: Executive Orders and Presidential Power. Princeton University Press.

McCarty, Nolan. 2000. 'Presidential Pork: Executive Veto Power and Distributive Politics'. American Political Science Review 94(1):117-29.

Milkis, Sidney, Jesse Rhodes, and Emily Charnock. 2012. 'What Happened to Post-Partisanship? Barack Obama and the New American Party System'. Perspectives on Politics 10(1):57-76.

Nielson, Daniel L. 2003. 'Supplying Trade Reform: Political Institutions and Liberalization in MiddleIncome Presidential Democracies'. American Journal of Political Science 47(3):470-91.

O’Halloran, Sharyn. 1994. Politics, Process, and American Trade Policy. Ann Arbor, MI: University of Michigan Press.

Rottinghaus, Brandon, and Elvin Lim. 2009. 'Proclaiming Trade Policy: "Delegated Unilateral Powers" and the Limits on Presidential Unilateral Enactment of Trade Policy'. American Politics Research 37(6): 1003-023.

Rudalevige, Andrew. 2002. Managing the President's Program: Presidential Leadership and Legislative Policy Formulation. Princeton, NJ: Princeton University Press.

Stathis, Stephen W. 2014. Landmark Legislation, 1774-2012: Major US Acts and Treaties. Washington, DC: CQ Press.

Stevenson, Richard W., and Elizabeth Becker. 2003. 'After 21 Months, Bush Lifts Tariff on Steel Imports', New York Times, 5 December 5. Available at http://www.nytimes.com/2003/12/05/us/after-21months-bush-lifts-tariff-on-steel-imports.html, accessed 1 May 2015. 
Tran, Hoa Phu Duy. 2011. Industrial Diversity and Economic Performance: A Spatial Analysis. Dissertation, University of Nebraska-Lincoln.

Wolman, Paul. 1992. Most Favored Nation: The Republican Revisionists and U.S. Tariff Policy, 1897-1912. Chapel Hill, NC: University of North Carolina Press.

Zegart, Amy. 2011. 'The Domestic Politics of Irrational Intelligence Oversight'. Political Science Quarterly 126(1):1-25. 